\title{
Effect of altering the intervals between consecutive superovulatory doses of porcine follicle-stimulating hormone on ovarian responses and embryo yields in anestrous ewes
}

\author{
P.M. Bartlewski ${ }^{\text {a,* }}$, M. Murawski ${ }^{\text {b }}$, T. Schwarz ${ }^{c}$, M.E.F. Oliveira ${ }^{\mathrm{d}}$ \\ a Department of Biomedical Sciences, Ontario Veterinary College, University of Guelph, Guelph, N1G 2W1, Ontario, Canada \\ b Department of Animal Biotechnology, Agricultural University of Kraków, 30-248 Cracow, Poland \\ c Department of Swine and Small Animal Breeding, Agricultural University of Kraków, 30-059 Cracow, Poland \\ d Department of Preventative Veterinary Medicine and Animal Reproduction, School of Agricultural and Veterinarian Sciences, São Paulo \\ State University (Unesp), Jaboticabal, São Paulo, 14.884-900, Brazil
}

\section{A R T I C L E I N F O}

\section{Article history:}

Received 20 December 2016

Accepted 3 March 2017

Available online 6 March 2017

\section{Keywords:}

Sheep

Anestrus

Superovulation

Follicle-stimulating hormone

Estradiol

\begin{abstract}
A B S T R A C T
The effect of varying intervals between successive gonadotropin injections on the superovulatory outcomes in anestrous Rideau Arcott ewes superstimulated for ovarian follicular development with multiple doses of porcine FSH (pFSH) was evaluated in a single study. Twenty-five animals received six $(1 \times 2.5 \mathrm{ml}$ and $5 \times 1.25 \mathrm{ml})$ injections of Folltropin ${ }^{\circledR}-\mathrm{V}$ given at 0800 and $1600 \mathrm{~h}$ or at 0800 and $2000 \mathrm{~h}$ in Group $1(n=9)$ or Group $2(n=16)$, respectively. An i.m. injection of $500 \mathrm{IU}$ of equine chorionic gonadotropin (eCG; Folligon ${ }^{\circledR}$ ) was given concurrently with the first pFSH dose. Time of estrus was synchronized among ewes with intravaginal sponges containing $60 \mathrm{mg}$ of medroxyprogesterone acetate (Veramix ${ }^{\circledR}$ ) that were left in place for 14 days; sponges were removed at the time of the 5 th $\mathrm{pFSH}$ injection. Six days after insertion of MAP sponges, all ewes received an i.m. injection of estradiol- $17 \beta$ dissolved in $1 \mathrm{ml}$ of sesame oil ( $350 \mu \mathrm{g} / \mathrm{ewe})$ to synchronize follicular wave emergence. Following the last pFSH dose, all animals were given a single i.m. injection of $50 \mu \mathrm{g}$ of gonadotropin-releasing hormone $\left(\mathrm{GnRH}\right.$; Cystorelin $\left.{ }^{\circledR}\right)$ to induce ovulations before placing in a pen with four fertile rams for $36 \mathrm{~h}$. The ovarian responses were assessed and embryos recovered surgically 7 days after GnRH injections. The mean number of corpora lutea was greater $(P<0.05)$ in Group 1 compared with Group 2 ewes $(21.0 \pm 2.9$ compared with $10.4 \pm 1.6$, respectively; mean \pm SEM) but there was no difference $(P>0.05)$ in the number of transferable embryos ( $5.4 \pm 2.4$ compared with $5.4 \pm 1.3 /$ ewe, respectively), and Group 1 animals had significantly more degenerated embryos than Group 2 ewes ( $2.6 \pm 1.2$ compared with $0.6 \pm 0.3$ /ewe, respectively). A superovulatory protocol wherein pFSH injections were given at 0800 and $1600 \mathrm{~h}$ was more effective in terms of inducing multiple ovulations than the protocol with 12-h intervals between consecutive pFSH doses, but it was not associated with an increased production of transferable quality embryos by anestrous ewes.
\end{abstract}

(c) 2017 Elsevier B.V. All rights reserved.
* Corresponding author at: Department of Biomedical Sciences, Ontario Veterinary College, University of Guelph, 50 Stone Road, Guelph, ON, N1G 2W1, Canada.

E-mail address: pmbart@uoguelph.ca (P.M. Bartlewski).

\section{Introduction}

Intensive research efforts aimed to establish effective superovulatory protocols and to augment the application of multiple ovulation and embryo transfer (MOET) 
programs, laparoscopic ovum pick up (LOPU), and other related reproductive technologies in small ruminants have constantly been in demand (Candappa and Bartlewski, 2011; Bartlewski et al., 2016). The viability rate of in vitroproduced (IVP) embryos is less than that of embryos obtained using MOET procedures (Paramio, 2010) and the MOET-derived embryos have greater cryotolerance compared with IVP-derived embryos (Massip et al., 1995). Therefore, even though both technologies can be employed to maximize genetic gain in livestock species (Paramio, 2010; Candappa and Bartlewski, 2011) and in conservation programs (Souza et al., 2011), superovulatory treatments remain a primary choice to produce multiple embryos.

A majority of superovulatory protocols currently used are cumbersome and may be associated with undesirable or residual effects (e.g., ovarian hyperstimulation, ovarian cysts, luteinized unovulated follicles, etc.; El-Gayar and Holtz, 2005; Bartlewski et al., 2015, 2016). The most frustrating aspect of problems with superovulatory treatments is tremendous variability in ovulatory responses and embryo yields among individual animals (Bartlewski et al., 2016). One possible reason for such adverse effects and unpredictability of superovulatory outcomes is the dose and frequency of gonadotropin injections given to donor animals (Baldassarre and Karatzas, 2004). Previous studies in estrous cycling and seasonally anovular ewes (Duggavathi et al., 2004, 2005; Barrett et al., 2006, 2007) have shown that there exists a threshold concentration of follicle-stimulating hormone (FSH) that needs to be surpassed to stimulate the entry of small antral follicles into waves of follicular development (i.e., follicles growing synchronously to ostensibly ovulatory diameters before regression or ovulation; Bartlewski et al., 1999, 2011); typically, a follicular wave in sheep consists of 1-3 follicles. Truncation of FSH peaks effectively prevents follicle-wave emergence, but injections of physiologic concentrations of ovine FSH (oFSH) re-initiate follicle-wave emergence in ewes (Barrett et al., 2006, 2007). Two injections of exogenous oFSH given $8 \mathrm{~h}$ apart induced the emergence of a new follicular wave approximately 0.5 days after treatment, even in the presence of large antral follicles from the previous wave of ovarian follicular development (Duggavathi et al., 2004, 2005). During the 3- or 4-day superovulatory protocols in ewes, consecutive FSH doses are usually administered every $12 \mathrm{~h}$ (Bartlewski et al., 2016). Variability in responses to superovulatory treatments suggests that, at these regular intervals, the increases in serum concentrations of FSH may not be sufficiently adequate to consistently induce the emergence of multiple ovarian follicles, especially after the removal of exogenous progestin source, which results in increased FSH clearance rates (Bartlewski et al., 2008b). This problem could potentially be eliminated by increasing a dose of FSH per injection or more frequent administration of exogenous FSH. Increasing the FSH dose may result in ovarian hyperstimulation in some donor animals. Shortening the intervals between two consecutive FSH injections given on the same day, therefore, appears to be a more desirable option to attain the peak concentration of the gonadotropin capable of stimulating the emergence and growth of ovarian antral follicles.
The main objective of the present study was to compare superovulatory responses in anestrous ewes subjected to two protocols differing in the timing of exogenous FSH injections (given every $12 \mathrm{~h}$ or daily at 0800 and $1600 \mathrm{~h}$ ). Anestrous sheep were chosen for this trial as the consistency for superovulatory response is poor in seasonally anovular ewes (Bartlewski et al., 2008a).

\section{Materials and methods}

\subsection{Animals and superovulatory procedures}

The present experimental procedures were in compliance with the policies and guidelines established by the Canadian Council on Animal Care (CCAC) for animal research, and had been approved by the Animal Care Committee at the University of Guelph. This study performed at mid-anestrus (May-June) utilized 25 clinically healthy multiparous Rideau Arcott ewes. Animals were kept outdoors (with an easy access to indoor facilities) at the field research station in Ponsonby near Guelph, ON, Canada (43 $37^{\prime} \mathrm{N}, 80^{\circ} 21^{\prime} \mathrm{W}$ ) and were fed daily maintenance diets of alfalfa pellets with hay, water and mineral licks available ad libitum. All ewes were fitted with intravaginal sponges containing medroxyprogesterone acetate $(60 \mathrm{mg}$; Veramix ${ }^{\circledR}$, Pfizer Animal Health, Kirkland, QC, Canada) that were kept in place for 14 days (see Fig. 1 for details of experimental design). At 6 days after insertion of MAP sponges, all ewes were given an i.m. injection of estradiol-17 $\beta$ (Longwing International, Oakville, ON, Canada) dissolved in $1 \mathrm{ml}$ of sesame oil ( $350 \mu \mathrm{g} /$ ewe $)$ to synchronize time of follicular wave emergence. The ensuing superovulatory treatment consisted of 6 i.m. injections of porcine FSH (pFSH: Folltropin ${ }^{\circledR}-\mathrm{V}$, Bioniche Animal Health Canada Inc., Belleville, ON, Canada; $2.5 \mathrm{ml} \times 1$ and $1.25 \mathrm{ml} \times 5$ ), given at approximately 0800 and $1600 \mathrm{~h}$ (Group $1, n=9$ ) or 0800 and 2000 h (Group 2, $n=16$ ). An i.m. injection of 500 IU of equine chorionic gonadotropin (eCG; Folligon ${ }^{\circledR}$, Intervet Canada Ltd., Whitby, ON, Canada) was given concurrently with the first pFSH dose. MAP sponges were removed at the time of the 5th pFSH injection. Following the last pFSH dose and $24 \mathrm{~h}$ after MAP sponge withdrawal, all animals received a single i.m. injection of $50 \mu \mathrm{g}$ of gonadotropinreleasing hormone (GnRH; Cystorelin ${ }^{\circledR}$, Merial Canada Inc., Baie d'Urfe, QC, Canada) to synchronize the time of the preovulatory LH surge and ovulations among animals, and were relocated to a pen with Rideau Arcott rams fitted with crayon marking harnesses for the next $36 \mathrm{~h}$ (rams to ewes ratio of 1:4). All rams used in this experiment underwent routine breeding soundness evaluation $\sim 3$ weeks before superovulation of ewes in this study and were classified as satisfactory.

\subsection{Embryo collection and grading}

The number of corpora lutea (identified on the basis of projections from the surface of the ovary and the presence of the ovulatory stigmata; Bartlewski et al., 2008a,b) was recorded at laparotomy 7 days after GnRH injections. Food and water were withheld for $24 \mathrm{~h}$ before surgery. Surgical 


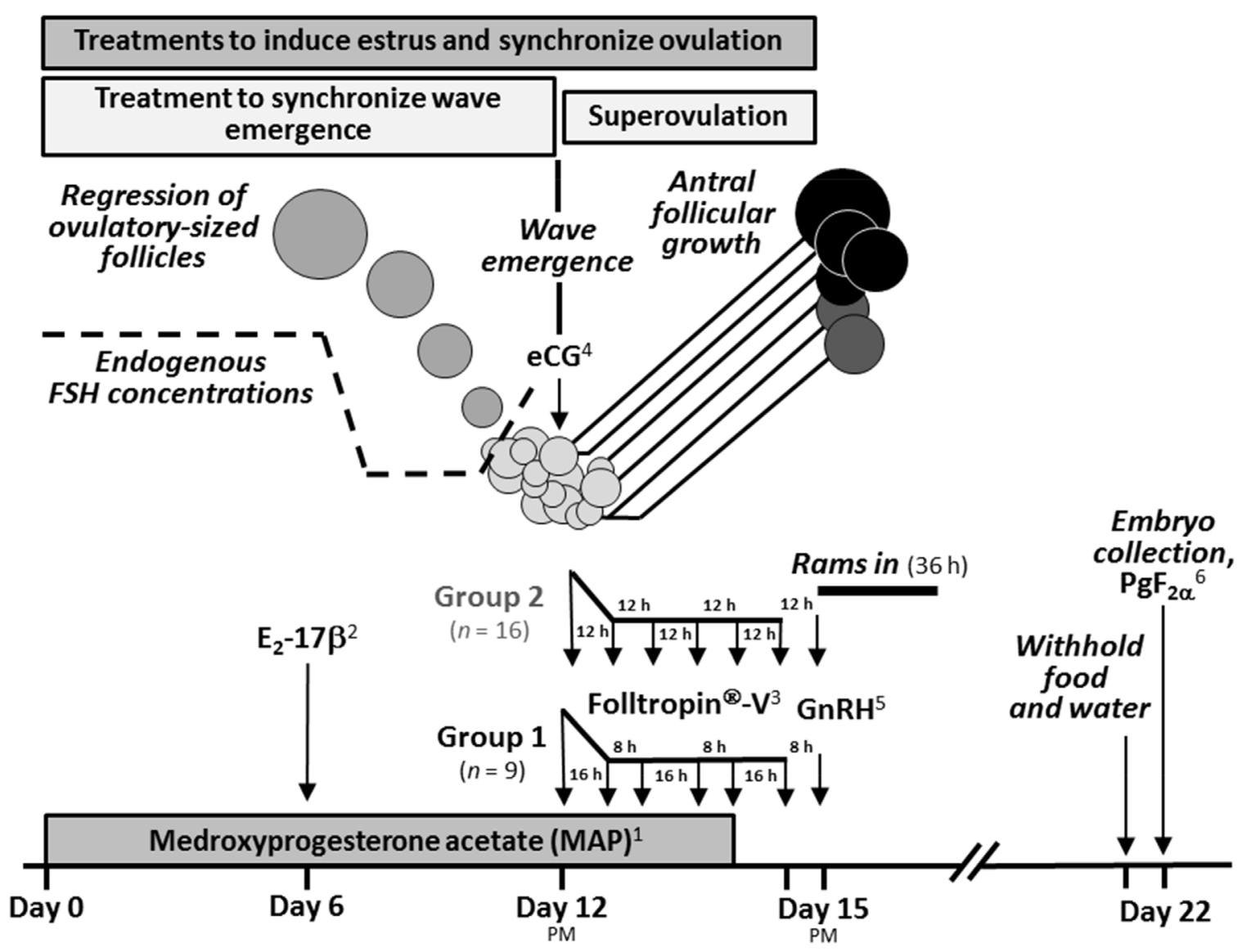

Fig. 1. A schematic of the experimental design including the superovulatory protocol with a transient suppression and re-synchronization of follicle wave emergence using a combined medroxyprogesterone acetate (MAP) ${ }^{1}$ /estradiol $17 \beta\left(E_{2}-17 \beta\right)$ treatment of anestrous ewes ${ }^{2}\left(350 \mu g\right.$ of $E_{2}-17 \beta$ in 1 ml of sesame oil i.m.); ${ }^{3}\left(1 \times 2.5 \mathrm{ml}\right.$ of Folltropin ${ }^{\circledR}-\mathrm{V}$ (porcine FSH) $+{ }^{4} 500 \mathrm{IU}$ eCG) $+5 \times 1.25 \mathrm{ml}$ of Folltropin ${ }^{\circledR}-\mathrm{V}$ i.m. administered at 0800 and $1600 \mathrm{~h}$ (Group 1 , $\mathrm{n}=9$ ) or at 0800 and $2000 \mathrm{~h}$ (Group $2, \mathrm{n}=16) ;{ }^{5}$ Cystorelin $^{\circledR}$ (50 $\mu \mathrm{g}$ i.m.); ${ }^{6}$ a luteolytic dose of a PgF ${ }_{2 \alpha}$ analogue (Lutalyse ${ }^{\circledR}, 10 \mathrm{mg}$ i.m.) given only to animals in which the difference between the number of corpora lutea and recovered embryos was $>5$. Other abbreviations used-eCG: equine chorionic gonadotropin; $\mathrm{GnRH}$ : gonadotropin-releasing hormone; and $\mathrm{PgF}_{2 \alpha}$ : prostaglandin $\mathrm{F}_{2 \alpha}$ analogue.

embryo recovery was performed under general anaesthesia induced with xylazine (Rompun ${ }^{\circledR}$, Bayer Animal Health, Ethobicoke, ON, Canada; $6 \mathrm{mg} / \mathrm{kg}$ i.m.) and ketamine (Ketamine Hydrochloride Injection, USP; Bioniche, Bellville, ON, Canada; $10 \mathrm{mg} / \mathrm{kg}$ i.v.). The reproductive tract was exposed (Fig. 2A), and both oviducts and uterine horns were flushed with $\sim 70 \mathrm{ml}$ of PBS containing $+1 \%$ bovine serum albumin + penicillin and streptomycin. The flushing was performed with a size 10 pediatric French catheter inserted into the uterine horn approximately $2 \mathrm{~cm}$ from the bifurcation of the uterus and kept in place by an inflatable balloon (Fig. 2B-D) and a 3 1/5 French Tomcat catheter inserted into the oviduct $1-2 \mathrm{~cm}$ from the utero-tubal junction (Fig. 2E-F). All recovered morulae and blastocysts were evaluated under a stereomicroscope, at $40 \times$ or $80 \times$ image magnification, and assigned a grade from 1 to 4 , with 1 being excellent, 2-good/fair, 3-poor, and 4-degenerated; embryo grades 1-3 were regarded as transferable quality embryos using previously described morphological criteria (Rubianes et al., 1995). After surgery, the ewes in which the difference between the number of $\mathrm{CL}$ and the number of all recovered embryos was $>5$ received an i.m. injec- tion of a luteolytic dose (15 mg/ewe) of prostaglandin $\mathrm{F}_{2 \alpha}$ (Lutalyse $^{\circledR}$; Upjohn, Orangeville, ON, Canada).

\subsection{Data analyses}

Comparisons between the two groups of ewes for all single time-point observations were computed using Student $t$-test (SigmaStat ${ }^{\circledR} 11.0$ for Windows ${ }^{\circledR}$; Systat Software Inc., Richmond, CA, USA). Proportions were analyzed by $\chi^{2}$-test and correlation analyses utilized the determination of Pearson's $r$ coefficients. Statistical differences were considered significant at $P<0.05$. All results are given as mean \pm standard error of the mean (SEM), unless otherwise stated.

\section{Results and discussion}

All ewes were distinctly marked by rams within $12 \mathrm{~h}$ of GnRH injections, had ovulations and had corpora lutea (CL) at the time of embryo collection. In Group 1, only one collection yielded no embryos (11\%) and two flushings (22\%) contained no transferable morulae or blastocysts. 

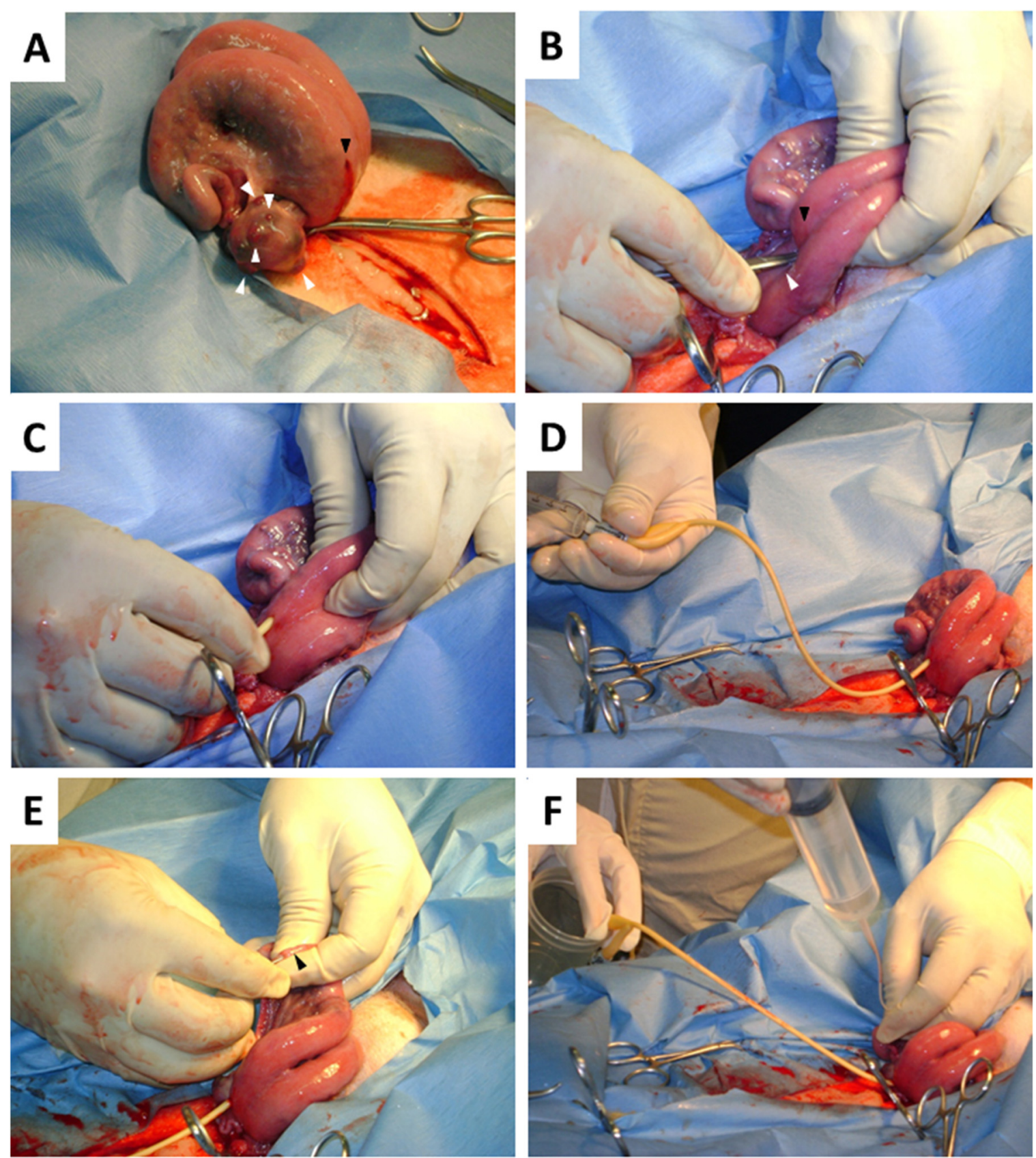

Fig. 2. Surgical embryo collection performed 7 days after the superovulatory treatment. (A) The ewe's reproductive tract was visually observed and all visible corpora lutea (projections from the surface of the ovary characterized by the presence of the ovulatory stigma; white arrowheads) enumerated; a visible puncture site from an earlier flushing of the left uterine horn (black arrowhead). The flushing was performed using a size 10 paediatric French catheter inserted into the uterine horn (black arrowhead; B, C) at the bifurcation of the uterus (white arrowhead) and kept in place by an inflatable balloon (D), and a $31 / 5$ French Tomcat catheter inserted into the oviduct (black arrowhead) approximately $1 \mathrm{~cm}$ from the utero-tubal junction (E). The oviducts and ipsilateral uterine horns were flushed with $\sim 70 \mathrm{ml}$ of medium per donor ewe (F) to retrieve embryos.

Fifty-six percent $(5 / 9)$ of donor animals had degenerated embryos but only one ewe (11\%) had unfertilized oocytes. In this subset on ewes, there were no significant correlations among the numbers of $\mathrm{CL}$ and embryos (neither total nor transferable/degenerated embryo counts). A lack of correlations between the ovulation rate and the number of retrievable embryos may be interpreted to sug- gest that oocyte quality and/or aberrant development of some preimplantation embryos could affect superovulatory results in the ewes receiving gonadotropin injections at 0800 and $1600 \mathrm{~h}$. In Group 2, 25\% of all collections (4/16) contained no embryos and less than the average number of transferable quality embryos was recovered from half of the ewes. There were $25 \%$ of donor animals that had 


\section{Table 1}

Superovulatory outcomes in anestrous Rideau Arcott ewes that were treated with multiple doses of porcine FSH with hormone injections given at 0800 and $1600 \mathrm{~h}$ (Group $1, n=9$ ) or at 0800 and $2000 \mathrm{~h}$ (Group 2,n=16). Ranges for all variables are given in parentheses.

\begin{tabular}{|c|c|c|}
\hline Variables & Group 1 & Group 2 \\
\hline No. of corpora lutea & $21.0 \pm 2.9^{a}(13-35)$ & $10.4 \pm 1.6^{\mathrm{b}}(4-27)$ \\
\hline Unfertilized oocytes & $1.3 \pm 1.3(0-12)$ & $2.1 \pm 0.9(0-11)$ \\
\hline $\begin{array}{l}\text { Blastocysts and morulae } \\
\text { (Grades 1-3) }\end{array}$ & $5.4 \pm 2.4(0-21)$ & $5.4 \pm 1.3(0-15)$ \\
\hline $\begin{array}{l}\text { Degenerated embryos } \\
\quad \text { (Grade 4) }\end{array}$ & $2.6 \pm 1.2^{\mathrm{a}}(0-10)$ & $0.6 \pm 0.3^{b}(0-3)$ \\
\hline $\begin{array}{l}\text { Total no. of recovered } \\
\text { embryos }\end{array}$ & $8.0 \pm 2.6(0-24)$ & $5.9 \pm 1.3(0-16)$ \\
\hline Embryo recovery rate (\%) & $47.0 \pm 11.2(0-100)$ & $47.0 \pm 8.1(0-92)$ \\
\hline
\end{tabular}

a,b Values with different superscripts differ $P<0.05$.

degenerated embryos and six of 16 ewes (38\%) had unfertilized oocytes. Obvious numerical differences existed in these values even though none of the proportions varied statistically $(P>0.05)$ between the two groups of superovulated ewes. Lastly, a significant positive correlation was recorded between the number of $\mathrm{CL}$ and all recovered embryos $(r=0.91 ; P<0.001)$ as well as between the numbers of CL and Grade $1-3$ embryos $(r=0.88, P<0.001)$.

Ovarian responses and embryo yields in the ewes of the present study are summarized in Table 1. Group 1 ewes exceeded $(P<0.05)$ Group 2 animals in the mean number of detected corpora lutea (CL). This difference is consistent with findings in earlier studies with estrous cyclic (September-March) Olkuska sheep (Murawski et al., 2015), in which the mean ovulation rate was also greater $(P \leq 0.01)$ in ewes receiving pFSH injections at 0800 and $1600 \mathrm{~h}$ compared with animals treated at 0800 and $2000 \mathrm{~h}$ for 3 days $(21.7 \pm 5.3$ compared with $11.7 \pm 3.8$, respectively; mean $\pm S D$ ). Therefore, it appears that the superovulatory regimen used in the present study effectively increases the number of ovulations in different genotypes of ewes (highly prolific Olkuska breed and moderately prolific Rideau Arcott ewes; Zieba et al., 2001; Bartlewski et al., 2017) and at different times of the year (breeding season and seasonal anestrus).

The number of degenerated morulae and blastocysts (Grade 4) was 4.3-fold greater in Group 1 than in Group 2 ewes $(2.6 \pm 1.2$ compared with $0.6 \pm 0.3$ /ewe, respectively; $P<0.05)$ but there were no significant differences in mean numbers of unfertilized eggs, viable (Grades 1-3) and all recovered embryos between the two groups of animals in the present study (Table 1). Previous studies have shown that superovulated ewes can be affected by the "ovulatory threshold"; a study conducted in Lacaune sheep demonstrated a significant decrease in fertilization rates and transferable embryo yields in animals with $>30$ ovulations (Torres et al., 1987). However, in the ewes of the present study, there was a significant positive correlation between the ovulatory response and the number of transferable quality embryos in Group 2 ewes. Moreover, retrospective inspections of data revealed that the mean ovulation rate was greater in animals that had degenerated embryos only in Group 2 ewes ( $16.5 \pm 3.7$ and $8.4 \pm 1.4$, for ewes with or without Grade 4 embryos, respectively; $P<0.05$ ), whereas the numbers of $\mathrm{CL}$ in similar subsets of Group 1 ewes were $21.8 \pm 4.7$ and $20.0 \pm 3.4$, respectively $(P>0.05)$. Collectively, these observations indicate that within the ranges of ovulation and fertilization rates recorded in the present study, no superovulatory threshold was observed, but the occurrence of degenerated embryos may be associated with increased ovulation rates in the ewes treated with pFSH at regular 12-h intervals. The values for ovulation and fertilization rate as well as the production of degenerated embryos were not associated in anestrous ewes that received gonadotropin injections daily at 0800 and $1600 \mathrm{~h}$ in the present study.

In previous studies using surgical embryo recovery after the application of various superovulatory protocols in ewes, the rate of embryo recovery ranged from $10 \%$ to $100 \%$ (Caroline and Summers, 1999; Shipley et al., 2007). While more efforts should apparently be directed to improve both the efficiency and repeatability of this procedure, it may also be feasible to maintain pregnancies in donor dams in which a number of unrecovered embryos is few so that the environment of the reproductive tract is sufficient to sustain developing conceptuses to term (i.e., $\leq 5$ lambs). A total of ten ewes (one of nine in Group 1 and nine of 16 in Group $2 ; P<0.05)$ did not receive a prostaglandin injection after embryo recovery. One of the Group 2 donor ewes sustained a pregnancy of twin lambs to full term (male: $5.5 \mathrm{~kg}$ and female: $4.8 \mathrm{~kg}$ born after 143 days of gestation following an i.m. injection of $20 \mathrm{mg}$ of dexamethasone (Unidex ${ }^{\circledR}$; Univet Pharmaceuticals, Milton, ON, Canada) on Day 141; Sir and Bartlewski, 2010); that ewe had nine luteal structures/CL and a total of five embryos (all Grade 1-3) were recovered from flushing medium. This fact best illustrates how viable embryos that are not recovered after superovulation may continue to develop normally.

To recapitulate, the ovulation rate was substantially enhanced in anestrous ewes that received pFSH injections at 0800 and $1600 \mathrm{~h}$ compared with the control subset of ewes treated at 12-h intervals, but this time increment for superovulatory treatments was associated with a greater number of degenerated embryos and consequently there was no significant increase in transferable embryo yields.

\section{Conflict of interest}

None to declare.

\section{Acknowledgements}

The authors would like to thank Pam Hasson at Ponsonby field research station for care and management of experimental animals, and Dr. Basil Alexander, Liz St. John and Patricia Seaton for their excellent technical assistance. The present project was supported by the NSERC (Natural Sciences and Engineering Research Council) Discovery grant to PMB.

\section{References}

Baldassarre, H., Karatzas, C.N., 2004. Advanced assisted reproduction technologies (ART) in goats. Anim. Reprod. Sci. 82-83, 255-266. Barrett, D.M.W., Bartlewski, P.M., Duggavathi, R., Davies, K.L., Rawlings, N.C., 2006. Suppression of follicle wave emergence in cyclic ewes by supraphysiologic concentrations of estradiol-17beta and induction 
with a physiologic dose of exogenous ovine follicle-stimulating hormone. Biol. Reprod. 75, 633-641.

Barrett, D.M.W., Duggavathi, R., Davies, K.L., Bartlewski, P.M., Bagu, E.T., Rawlings, N.C., 2007. Differential effects of various estradiol-17beta treatments on follicle-stimulating hormone peaks, luteinizing hormone pulses, basal gonadotropin concentrations, and antral follicle and luteal development in cyclic ewes. Biol. Reprod. 77, 252-262.

Bartlewski, P.M., Beard, A.P., Cook, S.J., Chandolia, R.K., Honaramooz, A., Rawlings, N.C., 1999. Ovarian antral follicular dynamics and their relationships with endocrine variables throughout the oestrous cycle in breeds of sheep differing in prolificacy. J. Reprod. Fertil. 115, 111-124.

Bartlewski, P.M., Alexander, B.D., King, W.A., 2008a. Ovarian and endocrine determinants of superovulatory responses in anestrous ewes. Small Ruminant Res. 75, 210-216.

Bartlewski, P.M., Alexander, B.D., Rawlings, N.C., Barrett, D.M.W., King, W.A., 2008b. Ovarian responses, hormonal profiles and embryo yields in anoestrous ewes superovulated with Folltropin ${ }^{\infty} \mathrm{V}$ after pretreatment with medroxyprogesterone acetate (MAP)-releasing vaginal sponges and a single dose of oestradiol-17 $\beta\left(E_{2}-17 \beta\right)$. Reprod. Domest. Anim. 43, 299-307.

Bartlewski, P.M., Baby, T.E., Giffin, J.L., 2011. Reproductive cycles in sheep. Anim. Reprod. Sci. 124, 259-268.

Bartlewski, P.M., Seaton, P., Szpila, P., Oliveira, M.E.F., Murawski, M., Schwarz, T., Kridli, R.T., Zieba, D.A., 2015. Comparison of the effects of pre-treatment with Veramix sponge (medroxyprogesterone acetate) or CIDR (natural progesterone) in combination with an injection of estradiol- $17 \beta$ on ovarian activity, endocrine profiles and embryo yields in cyclic ewes superovulated in the multiple-dose Folltropin-V (porcine FSH) regimen. Theriogenology 84 , 1225-1237.

Bartlewski, P.M., Seaton, P., Oliveira, M.E.F., Kridli, R.T., Murawski, M., Schwarz, T., 2016. Intrinsic determinants and predictors of superovulatory yields in sheep: circulating concentrations of reproductive hormones, ovarian status and antral follicular blood flow. Theriogenology 86, 130-143.

Bartlewski, P.M., Sohal, J., Paravinja, V., Baby, T., Oliveira, M.E.F., Murawski, M., Schwarz, T., Zieba, D.A., Keisler, D.H., 2017. Is progesterone the key regulatory factor behind ovulation rate in sheep? Domest. Anim. Endocrin. 58, 30-38.

Candappa, I.B.R., Bartlewski, P.M., 2011. A review of advances in artificial insemination (AI) and embryo transfer (ET) in sheep, with the special reference to hormonal induction of cervical dilation and its implications for controlled animal reproduction and surgical techniques. Open Reprod. Sci. J. 3, 162-175

http://www.benthamscience.com/open/torsj/articles/V003/162TORSJ.pdf.
Caroline, W., Summers, P.H., 1999. The recovery rate of embryos using eight different protocols of synchronization and superovulation in sheep. Jurnal Ilmu Ternak dan Veteriner 4, 13-19.

Duggavathi, R., Bartlewski, P.M., Barrett, D.M.W., Gratton, C., Bagu, E.T., Rawlings, N.C., 2004. Patterns of antral follicular wave dynamics and accompanying endocrine changes in cyclic and seasonally anestrous ewes treated with exogenous ovine follicle-stimulating hormone during the inter-wave interval. Biol. Reprod. 70, 821-827.

Duggavathi, R., Bartlewski, P.M., Agg, E., Flint, S., Barrett, D.M.W., Rawlings, N.C., 2005. The effect of the manipulation of FSH-peak characteristics on follicular wave dynamics in sheep: does an ovarian-independent endogenous rhythm in FSH secretion exist? Biol. Reprod. 72, 1466-1474.

El-Gayar, M., Holtz, W., 2005. Transfer of sexed caprine blastocysts freshly collected or derived from cultured morulae. Small Rumin. Res. 57, 151-156.

Massip, A., Mermillod, P., Dinnyes, A., 1995. Morphology and biochemistry of in-vitro produced bovine embryos: implications for their cryopreservation. Hum. Reprod. 10, 3004-3011.

Murawski, M., Schwarz, T., Grygier, J., Mikołajewska, N., Kochan, A., Nowak, A., Bartlewski, P.M., Mańka, G., Chmielowska, A., Kiecka, M., Paligai, M., Zięba-Przybylska, D., 2015. Effect of the interval between consecutive injections of porcine follicle-stimulating hormone $(\mathrm{pFSH})$ on the ovulation rate in superovulated ewes. Cracow, Poland In: International Conference Biotechnology and Welfare in Animal Husbandry, 15-16.

Paramio, M.T., 2010. In vivo and in vitro embryo production in goats. Small Rumin. Res. 89, 144-148.

Rubianes, E., Ibarra, D., Ungerfeld, R., Carbajal, B., de Castro, T., 1995. Superovulatory responses in anestrous ewes is affected by the presence of a large follicle. Theriogenology 43, 465-472.

Shipley, C.F.B., Buckrell, B.C., Mylne, M.J.A., Pollard, J., Hunton, J.R., 2007. Artificial insemination and embryo transfer in sheep. In: Youngquist, R.S., Threlfall, W.R. (Eds.), Current Therapy in Large Animal Theriogenology 2. Sounders Elsevier, St. Louis, MO, USA, pp. 629-641.

Sir, C., Bartlewski, P.M., 2010. Analyses of parental and seasonal influences on the synchrony of dexamethasone-induced lambing and lamb characteristics. Livest. Sci. 131, 119-124.

Souza, J.M.G., Batista, R.I.T.P., Melo, L.M., Freitas, V.J.F., 2011. Reproductive biotechnologies applied to the conservation of endangered ruminant - past, present and future. Revista Portuguesa em Ciências Veterinárias 110, 31-38.

Torres, S., Cognie, Y., Colas, G., 1987. Transfer of superovulated sheep embryos obtained with different FSH-P. Theriogenology 27, 407-419.

Zieba, D.A., Murawski, M., Wierzchos, E., 2001. Pattern of follicular development during the oestrous cycle of prolific Olkuska sheep. Archiv. Tierzucht. (Archives Animal Breeding) 44, 203-212. 